\title{
Etiology, multidrug resistance, and acute-phase proteins biomarkers as in equine septic arthritis
}

\section{Rodrigo Garcia Motta ${ }^{1^{*}}$ Lorrayne de Souza Araújo Martins ${ }^{1}$ (i) Rodrigo Costa da Silva ${ }^{2}$ (i) Fábio Vinícius Ramos Portilho ${ }^{10}$ Simony Trevizan Guerra ${ }^{1}$ André da Rocha Mota (i) $^{1}$

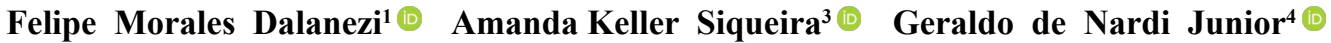 Fernando José Paganini Listoni ${ }^{1}$ [i] $\quad$ Márcio Garcia Ribeiro ${ }^{1}$ (i)}

${ }^{1}$ Faculdade de Medicina Veterinária e Zootecnia, Departamento de Produção Animal e Medicina Veterinária Preventiva, Universidade Estadual Paulista (UNESP), 18618-681, Botucatu, SP, Brasil. E-mail: rgmottafmvz@gmail.com. *Corresponding autor.

${ }^{2}$ Universidade do Oeste Paulista, Faculdade de Medicina Veterinária, Presidente Prudente, SP, Brasil.

${ }^{3}$ Faculdade de Medicina Veterinária, Universidade Estadual do Centro-Oeste (UNICENTRO), Guarapuava, PR, Brasil.

${ }^{4}$ Curso de Tecnologia de Agronegócio, Faculdade de Tecnologia de Botucatu (FATEC), Botucatu, SP, Brasil.

ABSTRACT: Etiology, multiple antibiotic resistance index, and acute-phase protein profile in the serum and synovial fluid of 44 horses presenting septic arthritis were investigated. Young animals up to 24 months of age not yet submitted to taming were sampled. Synovial samples from the horses were submitted to culture and bacterial isolates subjected to 18 antimicrobials to investigate the in vitro multidrug resistance pattern. Also, hematological aspects, fibrinogen, and serum levels of some acute-phase proteins (total protein, albumin, globulin, amyloid A, and C-reactive protein) were assessed. To statistical analysis, microbiological isolation were divided into four groups: G1 = animals with negative isolation, $G 2=$ isolation of Gram-negative bacteria, G3 = isolation of Gram-positive bacteria), and G4 =isolation of fungi. Microbial isolation was obtained from 77.2\% (32/44) of the synovial samples. Escherichia coli $(7 / 44=15.9 \%)$, Staphylococcus aureus $(5 / 44=11.4 \%)$, Streptococcus equi subsp. equi $(3 / 44=6.8 \%)$, Aspergillus niger $(3 / 44=6.8 \%)$, Pseudomonas aeruginosa $(2 / 44=4.5 \%)$, Streptococcus equi subsp. zooepidemicus $(1 / 44=2.3 \%)$, Trueperella pyogenes $(1 / 44=2.3 \%)$, and Rhodococcus equi $(1 / 44=2.3 \%)$ were prevalent bacterial agents. Aspergillus niger is reported by the first time as a primary agent of septic arthritis in horses. Gentamicin (84.9\%), marbofloxacin (79.3\%) and ceftriaxone (72.4\%) were the most effective antimicrobials, whereas high resistance of the isolates ( $>50 \%)$ was found to erythromycin (75.9\%), clarithromycin (75.9\%), penicillin (69\%), clindamycin (58.6\%), and streptomycin (55.2\%). Multiple antibiotic resistance index $(\geq 0.3)$ was identified in 50\% (16/32) of the isolates, with highest resistance in Gram-negative bacterial isolates. Serum levels of amyloid A, C-reactive protein, fibrinogen, globulin, and total protein, as well as the number of nucleated cells in the synovial fluid had values above the reference for horses, reinforcing acute-phase proteins as biomarkers in diagnosis of septic arthritis. We highlighted the diversity of microorganisms that may be involved in equine septic arthritis, the high resistance of bacterial isolates to conventional antimicrobials, the high lethality of young horses with septic arthritis, and importance of in vitro antimicrobial susceptibility pattern tests to therapeutic approaches in the disease.

Key words: septic arthritis, etiology, acute-phase proteins, synovial fluid, horses.

Etiologia, resistência antimicrobiana e proteínas de fase aguda como biomarcadores na artrite séptica equina

RESUMO: Foram investigados a etiologia, o indice de resistência múltipla aos antibióticos e o perfil de proteínas de fase aguda, no soro ou líquido sinovial, de 44 equinos com sinais clínicos compatíveis com artrite séptica. Foram amostrados animais até 24 meses de idade não submetidos a doma. As amostras de líquido sinovial dos 44 animais foram submetidas à cultura bacteriológica e fúngica, e os isolados bacterianos submetidos in vitro diante de 18 antimicrobianos visando investigar a multirresistência. Também foram avaliados os aspectos hematológicos e o fibrinogênio sérico, bem como os níveis séricos de certas proteínas de fase aguda (proteina total, albumina, globulina, amilóide sérico A e proteína $C$ reativa). O isolamento microbiano das amostras foi dividido em quatro grupos: G1 = animais com isolamento negativo; $G 2$ = isolamento de bactérias Gram-negativas; $G 3=$ isolamento de bactérias Gram-positivas e G4 = isolamento fúngico. O isolamento microbiano foi obtido em 77,2\% (32/44) das amostras de líquido sinovial. Escherichia coli $(7 / 44=15,9 \%)$, Staphylococcus aureus (5/44 = 11,4\%), Streptococcus equi subsp. equi (3/44 =6,8\%), Aspergillus niger $(3 / 44=6,8 \%)$, Pseudomonas aeruginosa $(2 / 44=4,5 \%)$, Streptococcus equi subsp. zooepidemicus (1/44 = 2,3\%), Trueperella pyogenes $(1 / 44=2,3 \%)$ e Rhodococcus equi $(1 / 44=2,3 \%)$ foram os patógenos mais frequentes. Aspergillus niger é relatado pela primeira vez como agente primário de artrite séptica em cavalos. Gentamicina (84,9\%), marbofloxacino $(79,3 \%)$ e ceftriaxona (72,4\%) foram os antimicrobianos mais eficazes, enquanto elevada resistência dos isolados (>50\%) foi encontrada para eritromicina (75,9\%), claritromicina (75,9\%), penicilina (69\%), clindamicina $(58,6 \%)$ e estreptomicina $(55,2 \%)$. O indice de resistência múltipla aos antibióticos $(\geq 0,3)$ foi identificado em $50 \%(16 / 32)$ dos isolados, com maior resistência obervada em bactérias Gramnegativas. Os níveis séricos de amilóide A, proteína C reativa, fibrinogênio, globulina e concentração total de proteínas, bem como o número de células nucleadas no líquido sinovial apresentaram valores acima da referência para equinos saudáveis, reforçando o uso destas proteínas de fase aguda como biomarcadores no diagnóstico da doença. O presente estudo enfatiza a diversidade de microrganismos que podem estar envolvidos na artrite séptica equina, a alta resistência dos isolados aos antimicrobianos convencionais, a alta mortalidade de equinos jovens com artrite séptica e a importância de realizar o tratamento da afecção com respaldo em testes de sensibilidade microbiana in vitro. Palavras-chaves: artrite séptica, etiologia, proteinas de fase aguda, líquido sinovial, cavalos. 


\section{INTRODUCTION}

Arthropathy is one of the main debilitating disease that affects horses. Joint diseases may cause lameness, loss of athletic and working performance, or functional incapacity (BECCATI et al., 2015). The disease is of septic or non-septic origin, which routinely are diagnosed based on clinical signs and abnormalities in the joint fluid. Septic arthritis is an infectious disease caused predominantly by bacteria, and less frequently by fungi and viral agents (TAYLOR et al., 2010).

Pathogens infect joints via the blood or lymphatic system (systemic dissemination). These microorganisms may invade joint structures secondary to traumatic inoculation (local infection) or by direct contamination after infiltration of drugs into the joint (iatrogenic route) and contamination during surgical procedures (COLAHAN et al., 1999; HALL, POLLOCK \& RUSSELL, 2012; ROSS \& DYSON, 2003).

Epidemiological data, history of local trauma or intra-articular therapy, immunosuppression conditions, and coinfections shoud be considerad in routine diagnosis of the disease. Clinical examination is required with an emphasis on the affected limbs and joints (OLIVE et al., 2014; STEEL, PANNIRSELVAM \& ANDERSON, 2013). Arthrocentesis, microbiological culture, in vitro antimicrobial susceptibility tests, synovial fluid analysis, and imaging tests have been indicated to confirm the disease as well (BECCATI et al., 2015; DE GRAUW et al., 2016; HALL, POLLOCK \& RUSSELL, 2012).

Articular drainage, and anti-inflammatory and antimicrobial drugs have been recommended in the therapy of septic arthritis. Articular drainage is indicated to remove microorganisms, fibrin, nucleated cells, and inflammatory debris that may damage the cartilage of the affected joint (HAERDILANDERER et al., 2010).

The antimicrobials used in the treatment of septic arthritis in horses can be applied in the following ways: oral, parenteral, intra-articular, and regional perfusion (HALL, POLLOCK \& RUSSELL, 2012; HARDY, 2006; SCHADE et al., 2019). Intraarticular and regional perfusion are the most efficient because they enable a high therapeutic concentration of drugs into the affected region and surrounding areas, as well as a decrease in the adverse systemic effects of high dosages. Nevertheless, the use of systemic broad-spectrum antimicrobials that reach therapeutic concentrations into joints is needed when more than one joint is affected (BECCATI et al., 2015; SCHADE et al., 2019).

The microbiological culture associated with in vitro antimicrobial susceptibility tests of causal agents may increase the efficiency of the therapy (BECCATI et al., 2015; FORRESU, LEPAGE \& CAUVIN, 2006; MORTON, 2005). Monotherapy or the combination of antimicrobials, e.g., $\beta$-lactams, fluoroquinolones, aminoglycosides, sulfonamides, macrolides, rifampicin and/or amphenicols have been used to treat equine septic arthritis (HALL, POLLOCK \& RUSSELL, 2012; MORTON, 2005) by oral, intra-articular, regional perfusion or systemic routes (BECCATI et al., 2015; HAERDILANDERER et al., 2010).

Multidrug-resistant bacteria are an emergent threat worldwide, including in the "One Health" concept, because they represent an issue in the therapy of infectious diseases that affect animals and humans (RIBEIRO et al., 2015).

Some proteins produced by bacteria during inflammatory processes have been used to diagnose infectious diseases among domestic animals (e.g., serum amyloid A, albumin, fibrinogen, and C-reactive protein) (HULTÉN et al., 2010; HULTÉN \& DEMMERS, 2010; JACOBSEN \& ANDERSEN, 2010). These main acute-phase proteins have been used as biomarkers of the inflammatory process in livestock and companion animals, particularly to establish the severity, prognosis, and outcomes of infectious diseases (ECKERSALL \& BELL, 2010). Nevertheless, the impact of some of these proteins in the diagnosis of septic arthritis of horses is poorly understood or unnoticed.

Few comprehensive studies have investigated the etiological complexity, bacterial multidrug resistance (CARSTANJEN, BOEHART \& CISLAKOVA, 2010; MORTON, 2005; SCHNEIDER et al., 1992), and acute-phase protein concentrations in the serum and synovial fluid of young horses with septic arthritis (JACOBSEN \& ANDERSEN, 2010). In this scenario, the present study aimed to investigate the etiology, multiple antibiotic resistance (MAR) index, and acute-phase protein profile in the serum and synovial fluid of 44 horses up 24 months of age with clinical signs compatible with septic arthritis.

\section{MATERIALS AND METHODS}

\section{Animals}

A convenience sampling of 44 horses presenting clinical signs compatible with septic arthritis were used. The animals belonged to farms 
in the Minas Gerais, Goias, and Sao Paulo states from Brazil, where equine farming is common. Synovial samples were collected from all horses that experienced signs suggestive of septic arthritis from 2017 to 2019 . Horses were eligible for the study if they presented clinical signs compatible with septic arthritis. In contrast, the exclusion criterion was the use of antimicrobial therapy within 30 days before the start of the study.

\section{Sampling}

Forty-four horses presenting clinical signs compatible with septic arthritis were sampled. From these, $23(52.3 \%)$ were male and $21(47.7 \%)$ female. The horses sampled were of various breeds: Quarter Horse $(15 / 44=34.1 \%)$, Paint Horse $(9 / 44=20.4 \%)$, Appaloosa $(3 / 44=6.8 \%)$, Mangalarga Marchador $(2 / 44=4.6 \%)$, Crioulo $(2 / 44=4.6 \%)$, Brazilian Sport Horse $(1 / 44=2.3 \%)$, and mixed breed $(12 / 44=27.2 \%)$.

The age of the animals ranged from 2 to 24 months (mo), as follows: $18.2 \%(8 / 44)$ from $2-3.9$ mo; $4.5 \%$ (2/44) from 4-5.9 mo; $11.4 \%(5 / 44)$ from 6-7.9 mo; 6.8\% (3/44) from 8-9.9 mo; 9.1\% (4/44) from 10-11.9 mo; 9.1\% (4/44) from 12-13.9 mo; $6.8 \%(3 / 44)$ from $14-15.9 \mathrm{mo} ; 9.1 \%(4 / 44)$ from 16 $17.9 \mathrm{mo} ; 4.5 \%$ (2/44) from $18-19.9 \mathrm{mo}, 9.1 \%(4 / 44)$ from $20-21.9 \mathrm{mo} ; 9.1 \%$ (4/44) from $22-23.9 \mathrm{mo}$; and $2.3 \%$ (1/44) with 24 mo.

Of the 44 horses sampled, 13 (29.5\%) animals died as a result of complications from septic arthritis. Of those, $5(38.5 \%)$ ranged from 2-3.9 mo, 2 (15.4\%) from 4-5.9 mo, 3 (23\%) from 6-7.9 mo, 1 $(7.7 \%)$ from $8.0-9.9 \mathrm{mo}, 1$ (7.7\%) from $10-11.9 \mathrm{mo}$ (7.7\%), and $1(7.7 \%)$ from $18-19.9$ mo.

Blood samples were collected in duplicate with and without anticoagulant (EDTA-15\%), from the external jugular vein using VacutainerTM (BD, Curitiba, Brazil). Serum samples were obtained after centrifugation $\left(1600 \mathrm{~g}, 10 \mathrm{~min}\right.$ ) and kept at $-20{ }^{\circ} \mathrm{C}$ until further biochemical analysis.

The synovial fluid was sampled after local rigorous antisepsis of the joint using a povidoneiodine solution $(2 \%)$. Then, $\sim 1.5 \mathrm{~mL}$ of synovial fluid was collected using a sterile $5-\mathrm{mL}$ disposable syringe and disposable needles (30x7). Only one synovial fluid sample was collected from each animal. Each of these synovial fluids was divided in duplicate, with and without EDTA (15\%). The clinical specimens were kept at $-20{ }^{\circ} \mathrm{C}$ until further microbiological, biochemical, and cellular analysis.

Different joints were sampled according to the clinical signs and affected limbs as follows: carpal $(17 / 44=38.7 \%)$, proximal interphalangeal $(10 / 44=22.7 \%)$, tarsal $(10 / 44=22.7 \%)$, femorotibiopatellar $(4 / 44=9.1 \%)$, and distal interphalangeal $(3 / 44=6.8 \%)$.

Among the 44 animals sampled with clinical signs compatible with septic arthritis, the probable origin of the infection was: hematogenic $(21 / 44=47.8)$, traumatic $(13 / 44=29.5 \%)$, joint infiltration $(7 / 44=15.9 \%)$, surgical complications $(2 / 44=4.5 \%)$, and umbilical infection $(1 / 44=2.3 \%)$.

\section{Clinical diagnosis of arthritis}

Clinical examination was carried out in all studied horses with an emphasis on limbs and joints (LEPAGE, PERRON \& CADORÉ, 2004). Joint swelling, edema, local temperature increase, pain at palpation, claudication of variable intensity, effusion, as well as systemic signs such as hyperthermia/ fever, inappetence, and/or decubitus were considered clinically compatible with septic arthritis and the animal enrolled in the study (OLIVE et al., 2014; STEEL, PANNIRSELVAM \& ANDERSON, 2013).

\section{Microbiological diagnosis}

The synovial fluid samples were streaked onto sheep blood agar (5\%), MacConkey agar and Sabouraud agar. The plates were incubated at $37^{\circ} \mathrm{C}$ under aerobic conditions for $120 \mathrm{~h}$. Simultaneously, the same samples were plated onto sheep blood agar (5\%) and brain heart infusion (BHI), and incubated at $37{ }^{\circ} \mathrm{C}$ under anaerobic conditions for $120 \mathrm{~h}$. The microorganisms were identified based on conventional phenotypic tests (QUINN et al., 2011).

\section{Antimicrobial susceptibility testing}

All bacteria isolated were subjected to in vitro antimicrobial susceptibility testing using the disk diffusion method, according to the Clinical Laboratory Standard Institute guidelines (CLSI, 2018). Eighteen different antimicrobials from 10 different classes used for oral, intra-articular, and regional perfusion and/or systemic route in the treatment of horses with clinical signs of arthritis were used: 1) cephalosporins (ceftriaxone, $30 \mu \mathrm{g}$; ceftiofur, $30 \mu \mathrm{g}$; cephalexin, $30 \mu \mathrm{g})$, 2) broad-spectrum penicillins (amoxicillin/clavulanic acid, $30 \mu \mathrm{g}$ ), 3) penicillin (penicillin, $10 \mathrm{IU}), 4)$ macrolides (azithromycin, 15 $\mu \mathrm{g}$; clarithromycin, $15 \mu \mathrm{g}$; erythromycin, $15 \mu \mathrm{g}$ ), 5) fluoroquinolones (enrofloxacin, $5 \mu \mathrm{g}$; ciprofloxacin, $5 \mu \mathrm{g}$; marbofloxacin, $5 \mu \mathrm{g})$, 6) aminoglycosides (gentamicin, $10 \mu \mathrm{g}$; amikacin, $30 \mu \mathrm{g}$; streptomycin, $30 \mu \mathrm{g})$, 7) rifamycin (rifampicin, $5 \mu \mathrm{g}$ ), 8) amphenicols (florfenicol, $30 \mu \mathrm{g}$ ), 9) sulfonamides 
(sulfamethoxazole/trimethoprim, $25 \mu \mathrm{g}$ ), and 10) lincosamides (clindamycin, $5 \mu \mathrm{g}$ ).

\section{Multiple antimicrobial resistance (MAR) index}

The MAR index was calculated as the ratio of the number of antimicrobial classes that each isolate showed resistance to the total number of the studied classes (10 classes). Isolates with $\mathrm{MAR} \geq 0.3$ were considered potential sources for the presence of resistant genes (KRUMPERMAN, 1983).

Hematological, synovial fluid and biochemical analyses Hematological analyses

Tests for red blood cell (RBC) count, hemoglobin (HGB), packed cell volume (PCV), mean corpuscular volume (MCV), mean corpuscular hemoglobin concentration (MCHC), white blood cell (WBC) count, segmented neutrophils, differential leukocytes, platelet count, and fibrinogen were performed using the blood samples with EDTA $(15 \%)$. A differential cell count was performed on slides of blood smears after staining (Diff-Quick ${ }^{\circledR}$ ) (MEDEIROS VEIGA et al., 2006).

\section{Serum protein analyses}

Serum samples were assessed for total protein, albumin, globulin, serum amyloid A, and C-reactive protein values using commercial kits. For the relationship of proteins, electrophoresis in polyacrylamide gel containing sodium dodecyl sulfate (SDS-PAGE) was performed. Molecular weights and variations in protein fractions were analyzed by computerized densitometry, in addition to albumin and immunoglobulin $\mathrm{G}$ (IgG) (JACOBSEN \& ANDERSEN, 2010; OLIVE et al., 2014).

\section{Cell count and protein in synovial fluid}

Nucleated cell count and total protein concentration in the synovial fluid were analyzed (OLIVE et al., 2014).

\section{Total and acute-phase protein analyses}

Serum samples were subjected to analysis of total proteins using vertical electrophoresis (Protean II XITM, Bio-Rad, Berkeley, USA) in polyacrylamide gel containing sodium dodecyl sulfate (SDS-PAGE) using commercial kits (HULTÉN; DEMMERS, 2010; OLIVE et al., 2014).

\section{Treatment}

After collection of synovial fluid, all animals were subjected to therapy with ceftiofur hydrochloride $(2.2 \mathrm{mg} / \mathrm{kg})$, every $24 \mathrm{~h}$, intramuscularly, for 7 days. Daily cleaning and dressings were also carried out (CONSTABLE et al., 2016).

\section{Statistical analysis}

All the data were entered onto an Excel spreadsheet and the animals divided into four groups depending on the microbiological results of synovial fluid, as follows: G1 = animals with negative isolation; $\mathrm{G} 2$ = isolation of Gram-negative bacteria; $\mathrm{G} 3$ = isolation of Gram-positive bacteria); G4 = isolation of fungi.

The breed, mortality, the anatomical location of arthritis, and the causal microorganism were analyzed by description statistics. Data were analyzed for normality of distribution by the Kolmogorov-Smirnov test. As some variables in the same group, or the same variable in different groups, did not present normal distribution, median (Md), percentile-25\% (P25), and percentile-75\% (P75) were used, as well as non-parametric tests. The significant differences in age and hematological and biochemical (serum and synovial fluid) variables among all groups were calculated using the KruskalWallis (KW) test. If significant, the respective data were submitted to a post-hoc test (Dunn test) to compare MAR index; this was considered just for G2 and G3, and analyzed using Mann-Whitney (U) test. The association between the variable gender and the microbiological isolation results (positive/ negative) was analyzed using Fisher's exact test. Odds Ratio (OR) was also calculated. Differences were considered significant when $p<0.05$. All tests were analyzed using the EpiInfoTM v.7.2.2.6 and GraphPad InStat v.3.06 software.

\section{RESULTS}

Microbiological isolation resulted positive in $32 / 44$ synovial fluid samples $(72.7 \%$; CI95\% 58.1-83.6\%).

Escherichia coli (7/44; 15.9\%), Staphylococcus aureus $(5 / 44 ; 11.4 \%)$, Streptococcus equi subsp. equi (3/44; 6.8\%), Aspergillus niger $(3 / 44 ; 6.8 \%)$, and Pseudomonas aeruginosa $(2 / 44 ; 4.5 \%)$ were the prevalent pathogens. Other enterobacteria $(5 / 44=11.3 \%)$, staphylococci $(4 / 44$ $=9.1 \%)$, Streptococcus equi subsp. zooepidemicus $(1 / 44=2.3 \%)$, Trueperella pyogenes $(1 / 44=2.3 \%)$ and Rhodococcus equi $(1 / 44=2.3 \%)$ were also isolated (Table 1). Strictly anaerobic microorganisms were not isolated.

Gentamicin (84.9\%), marbofloxacin $(79.3 \%)$ and ceftriaxone $(72.4 \%)$ were the 
Table 1 - Isolated microorganisms from synovial fluid samples of horses with septic arthritis.

\begin{tabular}{|c|c|c|c|}
\hline Groups & Microorganisms & Frequency & Percentage (\%) \\
\hline \multicolumn{4}{|c|}{ 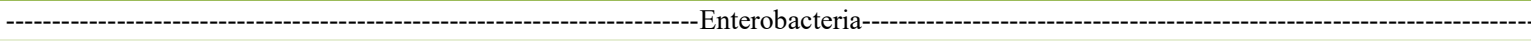 } \\
\hline & Escherichia coli & 7 & 15.9 \\
\hline & Enterobacter aerogenes & 2 & 4.5 \\
\hline & Enterobacter cloacae & 1 & 2.3 \\
\hline & Citrobacter freundii & 1 & 2.3 \\
\hline & Klebsiella pneumoniae & 1 & 2.3 \\
\hline & Subtotal & 12 & 27.3 \\
\hline \multicolumn{4}{|c|}{ 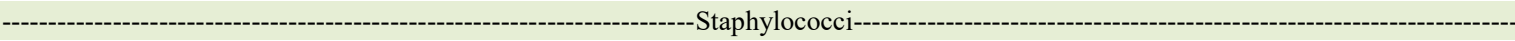 } \\
\hline & Staphylococcus aureus & 5 & 11.4 \\
\hline & Staphylococcus epidermidis & 3 & 6.8 \\
\hline & Staphylococcus sp. & 1 & 2.3 \\
\hline & Subtotal & 9 & 20.5 \\
\hline \multicolumn{4}{|c|}{ - } \\
\hline & Streptococcus equi subsp. equi & 3 & 6.8 \\
\hline & Streptococcus equi subsp. zooepidemicus & 1 & 2.3 \\
\hline & Subtotal & 4 & 9.1 \\
\hline \multicolumn{4}{|c|}{ 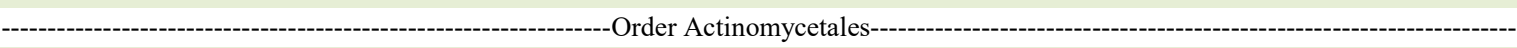 } \\
\hline & Trueperella pyogenes & 1 & 2.3 \\
\hline & Rhodococcus equi & 1 & 2.3 \\
\hline & Subtotal & 2 & 4.6 \\
\hline \multicolumn{4}{|c|}{ - Miscellaneous Gram-negative rods (non-enterobacteria)-- } \\
\hline & Pseudomonas aeruginosa & 2 & 4.5 \\
\hline & Subtotal & 2 & 4.5 \\
\hline \multicolumn{4}{|c|}{ 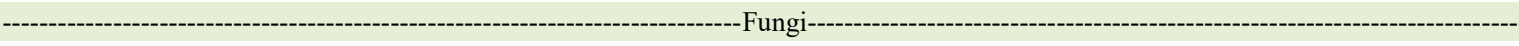 } \\
\hline & Aspergillus niger & 3 & 6.8 \\
\hline & Subtotal & 3 & 6.8 \\
\hline Negative & & 12 & 27.2 \\
\hline Total & & 44 & 100 \\
\hline
\end{tabular}

most effective antimicrobials. In contrast, high resistance of isolates was observed to erythromycin (75.9\%), clarithromycin $(75.9 \%)$, penicillin $(69 \%)$, clindamycin $(58.6 \%)$, streptomycin $(55.2 \%)$, cephalexin $(48.3 \%)$, rifampicin $(48.3 \%)$, amikacin (34.5\%), and florfenicol (34.5\%) (Table 2).

No microorganism was recovered from 12 $(27.3 \%)$ clinical specimens. From these animals with negative microbiological culture, $8(66.6 \%)$ presented the involvement of a single joint and $4(33.4 \%)$ revealed polyarthritis. Within this group, $5(41.6 \%)$ animals revealed mild claudication, without fever. Also, a lower lethality $(6.8 \%)$ was observed among these animals without isolation of microorganisms (G1) when compared to groups G2 (isolation of Gram-negative bacteria) and G3 (isolation of Gram-positive bacteria), with $13.7 \%$ and $9 \%$ lethality rates, respectively.

An MAR value of $\geq 0.3$ was identified in $50 \%$ of bacterial isolates with the highest indices for
Staphylococcus aureus $(\mathrm{MAR}=0.8)$, Pseudomonas aeruginosa $(\mathrm{MAR}=0.8)$, and Escherichia coli (MAR $=0.7$ ). Comparing G2 (Gram-negative bacteria isolation) and G3 (Gram-positive bacteria isolation) a significant difference was observed $(\mathrm{P}=0.0002)$ in MAR, as $\mathrm{G} 2$ presented higher MAR $(\mathrm{Md}=0.6)$ than $\mathrm{G} 3(\mathrm{Md}=0.1)$. It was also possible to identify a tendency toward lethality in animals that presented polyarthritis and an MAR value of $\geq 0.4$.

Age, lethality, and hematological and biochemical findings in the serum and synovial fluid of the studied horses are shown in table 3. Of those, $29.5 \%(13 / 44)$ horses died, and 69.2\% (9/13) presented polyarthritis, distributed in G1 $(n=3), G 2(n=6)$, and G3 $(n=4)$. The effectiveness of monotherapy with ceftiofur hydrochloride for 7 days in the clinical cure of septic arthritis cases was only $22.7 \%(10 / 44)$.

The average age of horses that died from septic arthritis was $9.3( \pm 6.97)$ mo, distributed as 
Table 2 - Isolated microorganisms from synovial fluid samples of horses with septic arthritis.

\begin{tabular}{|c|c|c|c|c|}
\hline \multirow[t]{2}{*}{ Group } & \multirow[t]{2}{*}{ Antimicrobial } & \multicolumn{3}{|c|}{ 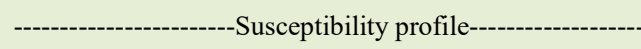 } \\
\hline & & $\mathrm{S}(\%)$ & I (\%) & $\mathrm{R}(\%)$ \\
\hline \multirow{3}{*}{ Cephalosporins } & Cephalexin & $10(34.5)$ & $5(17.2)$ & $14(48.3)$ \\
\hline & Ceftiofur & $16(55.2)$ & $10(34.5)$ & $3(10.3)$ \\
\hline & Ceftriaxone & $21(72.4)$ & $5(17.2)$ & $3(10.4)$ \\
\hline Broad-spectrum penicillins & Amoxicillin/clavulanic acid & $16(55.2)$ & $5(17.2)$ & $8(27.6)$ \\
\hline \multirow{3}{*}{ Macrolides } & Azithromycin & $9(31.0)$ & $7(24.1)$ & $13(44.9)$ \\
\hline & Clarithromycin & $4(13.8)$ & $3(10.3)$ & $22(75.9)$ \\
\hline & Erythromycin & $6(20.7)$ & $1(3.4)$ & $22(75.9)$ \\
\hline \multirow{3}{*}{ Fluoroquinolones } & Norfloxacin & $18(62.1)$ & $9(31.0)$ & $2(6.9)$ \\
\hline & Ciprofloxacin & $17(58.6)$ & $9(31.0)$ & $3(10.4)$ \\
\hline & Marbofloxacin & $23(79.3)$ & $4(13.8)$ & $2(6.9)$ \\
\hline \multirow{3}{*}{ Aminoglycosides } & Streptomycin & $6(20.7)$ & $7(24.1)$ & $16(55.2)$ \\
\hline & Gentamycin & $62(84.9)$ & $3(4.1)$ & $8(11.0)$ \\
\hline & Amikacin & $10(34.5)$ & $9(31.0)$ & $10(34.5)$ \\
\hline Rifamycin & Rifampicin & $11(37.9)$ & $4(13.8)$ & $14(48.3)$ \\
\hline Amphenicols & Florfenicol & $16(55.2)$ & $3(10.3)$ & $10(34.5)$ \\
\hline Sulfonamides & Trimethoprim/sulfamethoxazole & $15(51.7)$ & $7(24.1)$ & $7(24.2)$ \\
\hline Lincosamides & Clindamycin & $9(31.0)$ & $3(10.3)$ & $17(58.6)$ \\
\hline Penicillins & Penicillin & $6(20.7)$ & $3(10.3)$ & $20(69.0)$ \\
\hline
\end{tabular}

Legend: S, susceptible; I, intermediate; R, resistant; \%, percentage.

follow: $10(76.9 \%)$ ranged from $2-7.9$ mo and 3 (23.1\%) from $8.0-24$ mo. The prevalence in females $(80 \%)$ was higher than in males $(20 \%)$, with $\mathrm{OR}=2.0$ (CI 95\% 0.5-8.0), but no significant difference was observed $(\mathrm{P}=0.50)$.

All groups showed WBC counts and segmented neutrophils above the reference for horses. Serum levels of fibrinogen, globulin, C-reactive protein, and amyloid $\mathrm{A}$, as well as total protein and the number of nucleated cells in the synovial fluid revealed average values above reference. In contrast, serum albumin showed values below reference. Analysis of the concentration of serum amyloid A revealed a significant difference between $\mathrm{G} 2$ and $\mathrm{G} 1$, as well as between G3 and G1 $(\mathrm{P}<0.0001)$. The concentration levels of total protein in synovial fluid revealed a significant difference between G1 and G2 and between $\mathrm{G} 2$ and $\mathrm{G} 3(\mathrm{P}=0.0117)$.

Gram-positive bacteria were prevalent in the carpal joint, Gram-negative bacteria in the tarsal joint, and fungi in the patellofemoral joint. Negative isolation was more frequently observed in the proximal interphalangeal joint. No significant association was observed between the pathogens recovered from the synovial fluid and different joints, gender, or breed. No significant association was observed between high levels of acute-phase proteins that permit differentiate the isolation of Gramnegative or Gram-positve bacteria.

\section{DISCUSSION}

This study identified a high diversity of microorganisms being involved in septic arthritis in horses under 24 mo of age with a high lethality, in addition to a high resistance of bacterial isolates to conventional antimicrobials, which is a global emergent issue. It also identified serum levels of fibrinogen, globulin, C-reactive protein, and serum amyloid A above the reference for horses, reinforcing the use of these acute-phase proteins as biomarkers in the diagnosis of septic arthritis in young horses.

No significant differences were observed between the pathogens recovered from the synovial fluid and different joints, gender, or breed. Similar studies on equine arthritis (CARSTANJEN, BOEHART \& CISLAKOVA, 2010; STEEL, PANNIRSELVAM \& ANDERSON, 2013) also reported no significant association between these variables. Nevertheless, high lethality $(29.5 \%)$ was observed among the 44 sampled animals, particularly among foals $<8 \mathrm{mo}$. This result agreed with those from 
Table 3 - Hematological and biochemical findings in blood, serum and synovial fluid of 44 horses with arthritis to microorganisms isolated.

\begin{tabular}{|c|c|c|c|c|c|c|c|}
\hline VARIABLES & $\begin{array}{l}\text { Horses with } \\
\text { arthritis }\end{array}$ & $\begin{array}{c}\text { Culture- } \\
\text { negative (G1) }\end{array}$ & $\begin{array}{c}\text { Gram-negative } \\
\text { bacteria isolate } \\
\text { (G2) }\end{array}$ & $\begin{array}{l}\text { Gram-positive } \\
\text { bacteria isolate } \\
\text { (G3) }\end{array}$ & $\begin{array}{c}\text { Fungi } \\
\text { isolate (G4) }\end{array}$ & $\begin{array}{l}\mathrm{KW}(\mathrm{p}- \\
\text { value })\end{array}$ & $\begin{array}{l}\text { Reference } \\
\text { values }\end{array}$ \\
\hline \multicolumn{8}{|c|}{ 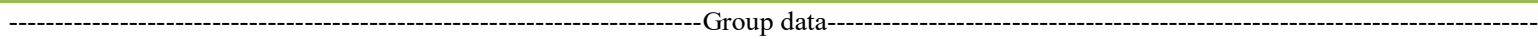 } \\
\hline $\begin{array}{l}\text { Number of } \\
\text { horses }\end{array}$ & $44(100 \%)$ & $12(31.8 \%)$ & $14(43.7 \%)$ & $15(46.9 \%)$ & $3(9.4 \%)$ & -- & -- \\
\hline $\begin{array}{l}\text { Number of } \\
\text { deaths }\end{array}$ & $13(29.5 \%)$ & $3(6.8 \%)$ & $6(13.7 \%)$ & $4(9 \%)$ & $0(0 \%)$ & -- & -- \\
\hline Age (months) & $11.5(6-17.2)$ & $10(5.8-16.5)^{\mathrm{a}}$ & $12.5(6.5-16.8)^{\mathrm{a}}$ & $8(3.5-18.0)^{\mathrm{a}}$ & $16(14-18)^{\mathrm{a}}$ & $\begin{array}{l}1.5950 \\
(0.6604)\end{array}$ & -- \\
\hline \multicolumn{8}{|c|}{ 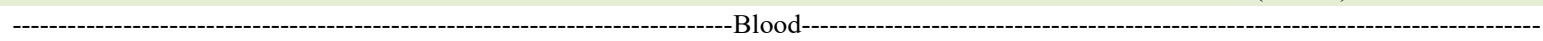 } \\
\hline $\begin{array}{l}\text { WBC } \\
(\text { cells } / \mu \mathrm{L})\end{array}$ & $\begin{array}{c}23,430 \\
(17,845- \\
28,105)\end{array}$ & $\begin{array}{c}19,895 \\
(17,290- \\
27,730)^{\mathrm{a}}\end{array}$ & $\begin{array}{c}20,870 \\
(17,662- \\
25,930)^{\mathrm{a}}\end{array}$ & $\begin{array}{c}25,890 \\
(19,899- \\
30,425)^{\mathrm{a}}\end{array}$ & $\begin{array}{c}24,980 \\
(21,990- \\
27,040)^{\mathrm{a}}\end{array}$ & $\begin{array}{c}3.4130 \\
(0.3323)\end{array}$ & $\begin{array}{l}5200- \\
13,900\end{array}$ \\
\hline $\begin{array}{l}\text { Segmented } \\
\text { neutrophils } \\
(\text { cells } / \mu \mathrm{L})\end{array}$ & $\begin{array}{c}18,290 \\
(15,272- \\
25,015)\end{array}$ & $\begin{array}{c}16,180 \\
(13,858- \\
25,510)^{\mathrm{a}}\end{array}$ & $\begin{array}{c}16,770 \\
(15,430- \\
22,498)^{\mathrm{a}}\end{array}$ & $\begin{array}{c}22,340 \\
(17,150- \\
26,545)^{\mathrm{a}}\end{array}$ & $\begin{array}{c}17,880 \\
(17,320- \\
21,485)^{\mathrm{a}}\end{array}$ & $\begin{array}{l}3.5440 \\
(0.3151)\end{array}$ & $2700-6700$ \\
\hline $\begin{array}{l}\text { Differential } \\
\text { leukocytes } \\
(\text { cells } / \mu \mathrm{L})\end{array}$ & $\begin{array}{c}3280(2498- \\
3915)\end{array}$ & $\begin{array}{c}3260 \\
(2360-3965)^{\mathrm{a}}\end{array}$ & $\begin{array}{c}3380 \\
(2265-3972)^{\mathrm{a}}\end{array}$ & $\begin{array}{c}3100 \\
(2770-3760)^{\mathrm{a}}\end{array}$ & $\begin{array}{l}3910 \\
(2515- \\
6065)^{\mathrm{a}}\end{array}$ & $\begin{array}{c}0.2909 \\
(0.9617)\end{array}$ & $1100-5300$ \\
\hline $\begin{array}{l}\mathrm{RBC}\left(\mathrm{x} 10^{6}\right. \\
\text { cells } / \mu \mathrm{L})\end{array}$ & $6.7(6-8)$ & $6.5(5.7-7.7)^{\mathrm{a}}$ & $6.7(6.3-7.9)^{\mathrm{a}}$ & $6.8(5.7-8.2)^{\mathrm{a}}$ & $5.7(5.4-9)^{\mathrm{a}}$ & $\begin{array}{c}0.9359 \\
(0.8168)\end{array}$ & $6.4-10$ \\
\hline $\begin{array}{l}\text { Hematocrit } \\
(\%)\end{array}$ & $32.5(27-42)$ & $\begin{array}{c}33 \\
(29.8-39.2)^{\mathrm{a}}\end{array}$ & $\begin{array}{c}37.5(27.5- \\
44.1)^{\mathrm{a}}\end{array}$ & $32(27-41.4)^{\mathrm{a}}$ & $\begin{array}{c}27 \\
(23.5- \\
46.8)^{\mathrm{a}}\end{array}$ & $\begin{array}{c}0.7218 \\
(0.8681)\end{array}$ & $32-47$ \\
\hline $\begin{array}{l}\text { Hemoglobin } \\
(\mathrm{g} / \mathrm{dL})\end{array}$ & $\begin{array}{l}10.2(9.2- \\
12.6)\end{array}$ & $\begin{array}{c}10.2 \\
(9.3-11.8)^{\mathrm{a}}\end{array}$ & $10.3(9.6-13.6)^{\mathrm{a}}$ & $9.5(9.2-10.8)^{\mathrm{a}}$ & $\begin{array}{c}9.5 \\
(8.2-15.8)^{\mathrm{a}}\end{array}$ & $\begin{array}{c}0.7788 \\
(0.8545)\end{array}$ & $11-17$ \\
\hline $\mathrm{MCV}(\mathrm{fl})$ & $\begin{array}{c}44.1 \\
(38.8-47.8)\end{array}$ & $\begin{array}{c}46.9 \\
(41.4-49.8)^{\mathrm{a}}\end{array}$ & $\begin{array}{c}43.9(41.9- \\
47.8)^{\mathrm{a}}\end{array}$ & $38.6(33-47.6)^{\mathrm{a}}$ & $\begin{array}{c}40 \\
(36.9- \\
43.6)^{\mathrm{a}}\end{array}$ & $\begin{array}{l}3.3140 \\
(0.3456)\end{array}$ & $39-52$ \\
\hline $\mathrm{MCHC}(\%)$ & $\begin{array}{c}34.1 \\
(32.9-35.5)\end{array}$ & $\begin{array}{c}33.8 \\
(33.1-34.5)^{\mathrm{a}}\end{array}$ & $\begin{array}{c}33.9(32.9- \\
35.2)^{\mathrm{a}}\end{array}$ & $35.1(34-37)^{\mathrm{a}}$ & $\begin{array}{c}35 \\
(32.6-35)^{\mathrm{a}}\end{array}$ & $\begin{array}{l}3.9810 \\
(0.2635)\end{array}$ & $31-35$ \\
\hline $\begin{array}{l}\text { Platelets } \\
\left(10^{3} / \mathrm{mm}^{3}\right)\end{array}$ & $\begin{array}{c}151.9 \\
(90-210.1)\end{array}$ & $\begin{array}{c}210.5 \\
(141.6- \\
231.1)^{\mathrm{a}}\end{array}$ & $\begin{array}{c}142.5(87.8- \\
206.3)^{\mathrm{a}}\end{array}$ & $\begin{array}{c}111.1(83.5- \\
177)^{\mathrm{a}}\end{array}$ & $\begin{array}{c}92(84.5- \\
139)^{\mathrm{a}}\end{array}$ & $\begin{array}{c}6.3720 \\
(0.0948)\end{array}$ & $100-270$ \\
\hline $\begin{array}{l}\text { Fibrinogen } \\
(\mathrm{mg} / \mathrm{dL})\end{array}$ & $\begin{array}{c}490 \\
(340-592.5)\end{array}$ & $\begin{array}{c}485 \\
(300-595)^{\mathrm{a}}\end{array}$ & $\begin{array}{c}535(467.5- \\
576.2)^{\mathrm{a}}\end{array}$ & $410(330-520)^{\mathrm{a}}$ & $\begin{array}{c}620 \\
(470-665)^{\mathrm{a}}\end{array}$ & $\begin{array}{l}3.4610 \\
(0.3259)\end{array}$ & $100-400$ \\
\hline \multicolumn{8}{|c|}{ 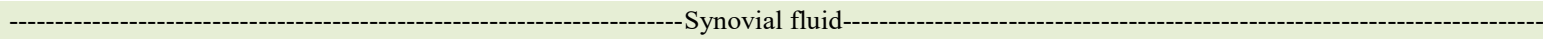 } \\
\hline $\begin{array}{l}\text { Nucleated cells } \\
(\text { cells } / \mu \mathrm{L})\end{array}$ & $\begin{array}{c}1411 \\
(615-2,772)\end{array}$ & $\begin{array}{c}1590 \\
(598-2304)^{\mathrm{a}}\end{array}$ & $\begin{array}{c}2096(792- \\
2777)^{\mathrm{a}}\end{array}$ & $\begin{array}{c}1220(368- \\
1784)^{\mathrm{a}}\end{array}$ & $\begin{array}{c}1890 \\
(1438- \\
3356)^{\mathrm{a}}\end{array}$ & $\begin{array}{l}2.2190 \\
(0.5283)\end{array}$ & $87-167$ \\
\hline $\begin{array}{l}\text { Total protein } \\
(\mathrm{g} / \mathrm{dL})\end{array}$ & $4.0(3.3-5.1)$ & $3.9(3.2-4.5)^{\mathrm{ab}}$ & $5.2(4.7-5.6)^{b}$ & $3.7(3.1-4)^{\mathrm{a}}$ & $3.8(3-4)^{\mathrm{ab}}$ & $\begin{array}{l}11.0030 \\
(0.0117)\end{array}$ & $<1.3$ \\
\hline \multicolumn{8}{|c|}{ - } \\
\hline $\begin{array}{l}\text { Albumin } \\
(\mathrm{mg} / \mathrm{dL})\end{array}$ & $2.3(1.9-2.8)$ & $2.0(1.8-2.4)^{\mathrm{a}}$ & $2.2(2-2.8)^{\mathrm{a}}$ & $2.7(2.4-3)^{\mathrm{a}}$ & $\begin{array}{c}2.1 \\
(1.9-2.4)^{\mathrm{a}}\end{array}$ & $\begin{array}{l}5.8270 \\
(0.1203)\end{array}$ & $2.6-3.7$ \\
\hline $\begin{array}{l}\text { Serum amyloid } \\
\mathrm{A}(\mathrm{mg} / \mathrm{dL})\end{array}$ & $\begin{array}{c}265 \\
(150-432.5)\end{array}$ & $\begin{array}{c}110 \\
(77.5-152.5)^{\mathrm{a}}\end{array}$ & $\begin{array}{c}380 \\
(282.5-532.5)^{\mathrm{b}}\end{array}$ & $\begin{array}{c}320 \\
(254.5-485)^{\mathrm{b}}\end{array}$ & $\begin{array}{c}250 \\
(192.5- \\
285)^{\mathrm{ab}}\end{array}$ & $\begin{array}{c}23.0600 \\
(<0.0001)\end{array}$ & $0.5-120$ \\
\hline $\begin{array}{l}\text { Globulin } \\
(\mathrm{mg} / \mathrm{dL})\end{array}$ & $5(4.1-5.6)$ & $5.1(4.4-6)^{\mathrm{a}}$ & $4.4(4.1-5)^{\mathrm{a}}$ & $5.1(4.1-5.4)^{\mathrm{a}}$ & $\begin{array}{l}5.6(5.2- \\
6.2)^{\mathrm{a}}\end{array}$ & $\begin{array}{c}4.0660 \\
(0.2544)\end{array}$ & $2.6-4.0$ \\
\hline $\begin{array}{l}\text { C-reactive } \\
\text { protein } \\
(\mathrm{mg} / \mathrm{dL})\end{array}$ & $9.5(8.1-19.8)$ & $8.2(7.8-9.2)^{\mathrm{a}}$ & $9.7(7.6-26.4)^{\mathrm{a}}$ & $17.7(9.5-24.4)^{\mathrm{a}}$ & $\begin{array}{l}9.4(8.6- \\
11.1)^{\mathrm{a}}\end{array}$ & $\begin{array}{c}7.0270 \\
(0.0710)\end{array}$ & $<7.5$ \\
\hline $\begin{array}{l}\text { Total protein } \\
(\mathrm{mg} / \mathrm{dL})\end{array}$ & $7.2(6.6-7.8)$ & $7(6.6-7.9)^{\mathrm{a}}$ & $6.8(6.4-7.4)^{\mathrm{a}}$ & $7.7(6.8-8)^{\mathrm{a}}$ & $\begin{array}{c}7.6(7.4- \\
8.2)^{\mathrm{a}}\end{array}$ & $\begin{array}{l}3.1410 \\
(0.3704)\end{array}$ & $5.8-8.7$ \\
\hline
\end{tabular}

Legend: WBC, white blood cells; RBC, red blood cells; MCV, mean corpuscular volume; MCHC, mean corpuscular hemoglobin concentration; KW, Kruskal-Wallis test.

*HULTÉN \& DEMMERS (2002), VEIGA et al. (2006), JACOBSEN (2007), VOS \& DUCHARME (2008), HEPWORTH-WARREN et al. (2015), AROS et al. (2017). 
a similar study (VOS \& DUCHARME, 2008) and could be due to the age of the animals enrolled in the current study, which were probably more susceptible to joint or systemic infections due to a certain immaturity of the immune system among young horses (CONSTABLE et al., 2016). In addition, a tendency to lethality was observed in horses sampled with signs of polyarthritis where bacteria with MAR were recovered; a fact that may have influenced in the high mortality of young animals.

The high complexity of agents reported in septic arthritis of horses (HEPWORTHWARREN et al., 2015; TAYLOR et al., 2010; VOS \& DUCHARME, 2008), particularly staphylococci, streptococci, enterobacteria, and some actinomycetes, indicates the wide variety of microorganisms that joints are exposed to. Therefore, the isolation of the causal agents of septic arthritis is a crucial step in adopting prophylactic and control management measures to avoid arthropathies in horse farms, as well as in instituting therapeutic approaches.

Enterobacteria form a complex Gramnegative group of microorganisms that belong to the enteric microbiota of humans, livestock, companion animals, and wildlife. These bacteria can be found in water, organic material, or contaminated materials for general use in equines. These pathogens are related to enteric and extra-enteric (ExPEC) opportunistic infections in domestic animals, characterized by a high set of virulence factors (QUINN et al., 2011). In this study, enterobacteria represented the most common group of pathogens isolated from the synovial fluid of horses with clinical signs of arthritis, which agrees with similar studies (MOTTA, et al., 2017; SCHNEIDER et al., 1992). Enterobacteria-induced articular infections have been related to traumatic contamination of the joint with feces or environmental material and are associated with systemic dissemination (STEEL, PANNIRSELVAM \& ANDERSON, 2013). Also, a high lethality was observed among sampled horses where Gram-negative bacteria (particularly E. coli) were isolated. Besides the risks of septic shock, horses infected with enterobacteria are exposed to additional complications regarding another type of shock caused by lipopolysaccharides (LPS) or endotoxin, a major component of the outer membrane of Gram-negative bacteria, and well-recognized as a common virulence factor of this group of pathogens (QUINN et al., 2011), which could have contributed to the lethality rates observed in horses sampled with enterobacteria.

$P$. aeruginosa is another Gram-negative bacterium, non-enterobacterial, that affects humans and animals. It is commonly reported in the intestinal tract of animals, in the environment, or causing nosocomial infections secondary to the contamination of surgical materials. The pathogen causes opportunistic clinical diseases in livestock, usually of a waterborne nature (QUINN et al., 2011). In the current study, P. aeruginosa was identified in two animals with clinical signs of septic arthritis, probably by invasion of the joint during intraarticular therapeutic approaches being contaminated by water and/or feces (STEEL, PANNIRSELVAM \& ANDERSON, 2013).

Staphylococci and streptococci are well-known Gram-positive bacteria inhabitants of the skin, mucosa (genitals, upper respiratory tract), and conjunctive microbiota of humans and animals and related to different clinical infections (FRIEDERICHS et al., 2010). Particularly in horses, $S$. equi subsp. equi is the causal agent of strangles, a highly prevalent contagious infection of the upper respiratory tract. $S$. aureus and $S$. equi subsp. equi were the most common pathogens isolated from the studied animals with clinical signs of septic arthritis. The high occurrence of both these Gram-positive cocci causing septic arthritis in horses can be attributed to their presence as commensal inhabitants of the skin in the joint region in domestic animals, including horses, which may favor secondary contamination of intra-articular procedures (iatrogenic route) or traumatic inoculation of the pathogens into the joint. Also, the systemic dissemination of some Grampositive microorganisms, i.e., S. equi subsp. equi and $S$. equi subsp. zooepidemicus from the upper respiratory tract should be considered in etiology (STEEL, PANNIRSELVAM \& ANDERSON, 2013).

Actinobacteria are a complex group of Gram-positive pleomorphic pathogens that affect animals and humans and are related to highimpact life-threatening diseases (tuberculosis, nocardiosis, rhodococcosis, and corynebacteriainduced infections), with relevant public health risks (CONSTABLE et al., 2016). Among these aerobic actinomycetes, $T$. pyogenes is usually reported as an inhabitant of the skin and mucosa of domestic animals, and involved in fly-related transmission in livestock farms. Despite their uncommon occurrence in equines, $T$. pyogenes-induced infections are characterized by pyogenic clinical manifestations, commonly refractory to conventional therapy, and poor prognosis (RIBEIRO et al., 2015). Rhodococcus equi is considered the agent mainly responsible for the high mortality of foals up to 6 months of age, causing pyogranulomatous pneumonia and ulcerative colitis (RIBEIRO et al., 2005). Also, septic and 
immune-mediated joint diseases produced by $R$. equi are common in horses. Unlike septic arthritis by $R$. equi, the immuno-mediated disease is induced by the deposition of immune complexes into the joint, but its isolation from the synovial fluid is not possible. In the current study, $R$. equi was identified in only one horse, probably secondary to a disseminated infection of the pathogen from lung or enteric infections (VÁZQUEZ-BOLAND et al., 2013).

The Aspergillus genus is an important group of anemophilic fungi widespread in the environment. Its occurrence has been associated with some opportunistic infections in horses (KRADIN \& MARK, 2008; LEPAGE, PERRON \& CADORÉ, 2004), mainly in immunosuppressed, young, or old animals (TUNEV et al., 1999). A. niger was isolated from three sampled horses with clinical signs of septic arthritis, probably due to contamination during intraarticular procedures or the spread of the agent from a primary pulmonary infection (LEPAGE, PERRON \& CADORÉ, 2004). To our knowledge, this is the first report of $A$. niger as a primary agent of septic arthritis in young horses.

Among the 44 horses, $12(27.3 \%)$ tested negative to microbiological isolation. This result agreed with those of similar studies (HEPWORTH-WARREN et al., 2015; TAYLOR et al., 2010) and these cases of arthropathies may have been caused by traumatic or degenerative conditions (SCHNEIDER et al., 1992), as well as of immune-mediated origin, i.e., $R$. equi-induced infection where no microorganism is present (VÁZQUEZ-BOLAND et al., 2013). No strictly anaerobic bacterium was isolated, which reveals the low influence of these pathogens in equine septic arthritis. These data agree with those of similar studies where animals with non-septic arthritis (e.g., traumatic) usually show no effusion or fever, and lower mortality (HEPWORTH-WARREN et al., 2015).

The use of antimicrobials is another factor that may contribute to the failure to recover microorganisms in cases of septic arthritis, although this situation was considered in the exclusion criteria of the current study. Nonetheless, this information is decisive and should be included in the anamneses of horses suspected of arthritis, particularly that of septic origin (TAYLOR et al., 2010). Another feature that could influence negative isolation is the low number of bacteria present in the joint, making it difficult to isolate the pathogens using conventional methods of diagnosis. Thus, the use of molecular techniques for the diagnosis of septic arthritis may increase the identification of microorganisms (CONSTABLE et al., 2016).
In this study, a clinical cure was identified in only $22.7 \%(10 / 44)$ of animals, which were treated exclusively with parenteral antimicrobials. The treatment of septic arthritis aimed to eliminate the microorganism that causes the disease, and to remove the harmful products of synovial inflammation and fibrin that can damage the articular cartilage. Therefore, to avoid chronic injuries and systemic complications, treatment of arthropathies should be started as soon as possible (HARDY, 2006; SCHADE et al., 2019).

$\beta$-Lactams and their derivatives (penicillin, cephalosporins), aminoglycosides (MORTON, 2005), and fluoroquinolones (HAERDI-LANDERER et al., 2010) are seen as the first-choice antimicrobials to treat equine septic arthritis. In the current study, gentamicin, marbofloxacin, and ceftriaxone were the most effective. These findings suggested that these antimicrobials may be effective alternatives in the therapy of septic arthritis in horses, although is strongly recommended that, if possible, treatments should be based on in vitro susceptibility pattern tests (MOTTA et al., 2017). Conversely, high resistance of isolates to various drugs was reported, e.g., to erythromycin, clarithromycin, penicillin, clindamycin, streptomycin, cephalexin, amikacin, and rifampicin. Curiously, some of these drugs are commonly used to treat clinical and surgical equine disorders, including septic arthritis, e.g., penicillin, amikacin, and streptomycin (MORTON, 2005; HEPWORTH-WARREN et al., 2015).

Furthermore, $50 \%$ of isolates showed multidrug resistance, especially $S$. aureus, $P$. aeruginosa, and $E$. coli, which could harbor genes related to multidrug resistance to conventional antimicrobials (SCHWARZ et al., 2010). In fact, the non-responsible use of antimicrobials has been implicated in the increase of selective pressure for multidrug-resistant bacteria, which is an emergent global issue. The routine use of antimicrobials for livestock and companion animals is an emerging concern and a central aspect of the "One Health" concept (RIBEIRO et al., 2015) to preserve these drugs for human therapy approaches.

Leukocytosis and neutrophilia have usually been reported in equine bacterial infections, including infectious arthropathies (AROS et al., 2017; HULTÉN et al., 2010; MEDEIROS VEIGA et al., 2006), which agrees with the hematological results observed among horses sampled with signs of septic arthritis. In addition, a high concentration of total protein and nucleated cells in the synovial fluid were observed in all studied groups, which corroborates 
similar studies on septic arthritis in horses described elsewhere (HEPWORTH-WARREN et al., 2015; HULTÉN et al., 2010; JACOBSEN \& ANDERSEN, 2010; LUDWIG et al., 2016; VOS \& DUCHARME, 2008). Also, a significant difference was observed in the total protein concentration in the synovial fluid in G2 (Gram-negative bacteria isolation) when compared to the other groups studied, a circumstantial evidence that may be suggestive of septic arthritis in horses from this group of pathogens.

Serum amyloid A, albumin, fibrinogen, and $\mathrm{C}$-reactive protein have been recognized as the main proteins that increase in an inflammatory process caused by microorganisms (HULTÉN \& DEMMERS, 2010; JACOBSEN \& ANDERSEN, 2010; VOS \& DUCHARME, 2008). In the current study, the serum concentration of fibrinogen, globulin, C-reactive protein, and serum amyloid A revealed values above the reference for horses. Serum amyloid A levels showed a significant difference between G2 (Gramnegative bacteria) and G1 (negative isolation) groups, as well as between G3 (Gram-positive bacteria) and G1. The difference observed between serum amyloid $\mathrm{A}$ and C-reactive protein could be because serum amyloid A represents a major acute-phase protein (shows a faster and greater increase), whereas C-reactive protein shows a moderate increase in the acute phase of the inflammatory response (a slow but longer increase). Nonetheless, among horses sampled, it was not possible to distinguish Gram-negative or Gram-positive infections from individual changes in acute-phase proteins tested; a fact that could to help clinicians in diagnosis of septic arthitis in horses.

In the same way, fibrinogen usually increases seven days after the beginning of inflammation, whereas albumin is a negative acutephase protein. Thus, in the horses sampled, albumin showed the expected decrease, while fibrinogen increased (JACOBSEN \& ANDERSEN, 2010). However, the time of sampling of the synovial fluid may be a factor that influenced the results from the sampled horses.

No use of speciation by MALDI-TOF MS or other automatic system diagnosis method, a convenience sampling of horses with clinical signs compatible with septic arthritis, and no classification of scores (gravity) of claudication in the sampled animals may be considered limitations of the current study.

\section{CONCLUSION}

Here we observed the etiological complexity of the microorganisms involved in septic arthritis of horses up to 2 years old, which highlights the importance of etiological diagnosis of the disease before initiating therapeutic procedures and of adopting control/prophylactic measures against the disease. The resistance of bacterial isolates and high lethality of young horses indicates the need for rational use of antimicrobials in equine practices and prior in vitro susceptibility tests to increases success in therapeutic approaches of septic arthritis.

\section{ACKNOWLEDGEMENTS}

The authors thank the Coordenação de Aperfeiçoamento de Pessoal de Nível Superior (CAPES), Brasil, for research productivity fellowships) PQ-1D - grant 306116/20162) given to Márcio Garcia Ribeiro.

\section{BIOETHICS AND BIOSECURITY COMMITTEE APPROVAL}

This study was approved by the Animal Use Ethics Committee of the School of Veterinary Medicine and Animal Sciences, Universidade Estadual Paulista (UNESP), Botucatu, SP, Brazil (protocol number 84/2018).

\section{DECLARATION OF CONFLICT OF} INTERESTS

The authors declare no conflict of interest. The founding sponsors had no role in the design of the study; in the collection, analyses, or interpretation of data; in the writing of the manuscript, and in the decision to publish the results.

\section{AUTHORS' CONTRIBUTIONS}

All authors contributed equally to the conception and writing of the manuscript. All authors critically revised the manuscript and approved the final version.

\section{REFERENCES}

AROS, K. et al. Haematological and serum biochemical reference values for urban-working equines in Chile. Austral journal of veterinary sciences, 2017. v.49, n.1, p.27-33. Available from: $<$ http://www.scielo.cl/scielo.php?script=sci arttext\&pid=S0719$81322017000100106 \& \operatorname{lng}=$ en $\& n r m=$ iso\&tlng $=$ en $>$. Accessed: Apr. 24, 2020.

BECCATI, F. et al. UltrasographicC FINDINGS IN 38 HORSES WITH SEPTIC ARTHRITIS/TENOSYNOVITIS. Veterinary Radiology \& Ultrasound, jan. 2015. v.56, n.1, p.68-76. Available from: <https://onlinelibrary.wiley.com/doi/abs/10.1111/ vru. $12183>$. Accessed: Apr. 23, 2020.

CARSTANJEN, B.;et al., Septic arthritis in adult horses. Polish journal of veterinary sciences, 2010. v.13, n.1, p.201-12. Available from: $<\mathrm{http}: / /$ www.ncbi.nlm.nih.gov/pubmed/21077452>. Accessed: Apr. 24, 2020.

CLINICAL AND LABORATORY STANDARDS INSTITUTE (CLSI). Document Vet08. Performance Standards for 
Antimicrobial Disk and Dilution Susceptibility Tests for Bacteria Isolated from Animals. Approved Standard, 4th. 2018, Wayne, PA, USA. Available from: <http://www.clsi.org >. Accessed: Apr. 24, 2020.

COLAHAN, P. T. et al. Equine medicine and surgery. 5th. ed. [S.1.]: Mosby, 1999.

CONSTABLE, P. et al. Veterinary Medicine: A textbook of the diseases of cattle, horses, sheep, pigs and goats - two-volume set. 1. ed. [S.1.]: Saunders Ltd., 2016. v.2.

ECKERSALL, P. D.; BELL, R. Acute phase proteins: Biomarkers of infection and inflammation in veterinary medicine. Veterinary Journal. Available from: <http://www.ncbi. nlm.nih.gov/pubmed/20621712>. Accessed: Apr. 24, 2020.

FORRESU, D.;et al.,. Septic bicipital bursitis, tendonitis and arthritis of the scapulohumeral joint in a mare. Veterinary Record 9 set. 2006. v.159, n.11, p.352-354. Available from: <http://www ncbi.nlm.nih.gov/pubmed/16963716>. Accessed: Apr. 24, 2020.

FRIEDERICHS, J. et al. Human bacterial arthritis caused by Streptococcus zooepidemicus: report of a case. International Journal of Infectious Diseases, set. 2010. v.14, n.SUPPL. 3, p.e233-e235. Available from: <http://www.ncbi.nlm.nih.gov/ pubmed/20004124>. Accessed: Apr. 24, 2020.

GRAUW, J. C. DE et al. Intra-articular treatment with triamcinolone compared with triamcinolone with hyaluronate: A randomised openlabel multicentre clinical trial in 80 lame horses. Equine Veterinary Journal, 1 mar. 2016. v.48, n.2, p.152-158. Available from: <http:// www.ncbi.nlm.nih.gov/pubmed/25377505>. Accessed: Apr. 24, 2020.

HAERDI-LANDERER, M. C. et al. Slow release antibiotics for treatment of septic arthritis in large animals. Veterinary Journal. Available from: <http://www.ncbi.nlm.nih.gov/ pubmed/19345594>. Accessed: Apr. 24, 2020.

HALL, M.;et al.,. Surgical treatment of septic physitis in 17 foals. Australian Veterinary Journal, dez. 2012. v.90, n.12, p.479-484. Available from: <https://www.ncbi.nlm.nih.gov/ pubmed/23186089>. Accessed: Apr. 23, 2020.

HARDY, J. Etiology, Diagnosis, and treatment of septic Arthritis, Osteitis, and Osteomyelitis in Foals. Clinical Techniques in Equine Practice, dez. 2006. v.5, n.4, p.309-317. Available from: $<$ https:// linkinghub.elsevier.com/retrieve/pii/S1534751606000965>. Accessed: Apr. 24, 2020.

HEPWORTH-WARREN, K. L. et al. Bacterial isolates, antimicrobial susceptibility patterns, and factors associated with infection and outcome in foals with septic arthritis: 83 cases (1998-2013). Journal of the American Veterinary Medical Association, 1 abr. 2015. v.246, n.7, p.785-793. Available from: $<$ http://www.ncbi.nlm.nih.gov/pubmed/25794129>. Accessed: Apr. 24, 2020.

HULTÉN, C. et al. Dynamics in serum of the inflammatory markers serum amyloid A (SAA), haptoglobin, fibrinogen and $\alpha 2$-globulins during induced noninfectious arthritis in the horse. Equine Veterinary Journal, 5 jan. 2010. v.34, n.7, p.699-704. Available from: <https://pubmed.ncbi.nlm.nih.gov/12455841/>. Accessed: Apr. 24, 2020.

HULTÉN, C; DEMMERS, S. Serum amyloid A (SAA) as an aid in the management of infectious disease in the foal: comparison with total leucocyte count, neutrophil count and fibrinogen. Equine Veterinary Journal, 2010. v.34, n.7, p.693-698. Available from: <https://pubmed.ncbi.nlm.nih.gov/12455840/>. Accessed: Apr. 24, 2020.

JACOBSEN, S.; ANDERSEN, P. H. The acute phase protein serum amyloid A (SAA) as a marker of inflammation in horses. Equine Veterinary Education, 5 jan. 2010. v.19, n.1, p.38-46. Available from: <http://doi.wiley.com/10.1111/j.2042-3292.2007. tb00550.x>. Accessed: Apr. 24, 2020.

KRADIN, R. L.; MARK, E. J. The pathology of pulmonary disorders due to Aspergillus spp. Archives of pathology \& laboratory medicine, abr. 2008. v.132, n.4, p.606-14. Available from: <http://www. ncbi.nlm.nih.gov/pubmed/18384212>. Accessed: Apr. 24, 2020.

KRUMPERMAN, P. H. Multiple antibiotic resistance indexing of Escherichia coli to identify high-risk sources of fecal contamination of foods. Applied and Environmental Microbiology, 1983. v.46, n.1, p.165-170. Available from: <https://www.ncbi.nlm.nih.gov/ pmc/articles/PMC239283/>. Accessed: Apr. 24, 2020.

LEPAGE, O. M.;et al., The mystery of fungal infection in the guttural pouches. The Veterinary Journal, jul. 2004. v.168, n.1, p.60-64. Available from: <http://www.ncbi.nlm.nih.gov/ pubmed/15158209>. Accessed: Apr. 24, 2020.

LUDWIG, E. K. et al. Serum and Synovial Fluid Serum Amyloid A Response in Equine Models of Synovitis and Septic Arthritis. Veterinary Surgery, 1 out. 2016. v.45, n.7, p.859-867. Available from: <http://doi.wiley.com/10.1111/vsu.12531>. Accessed: Apr. 24, 2020.

MEDEIROS VEIGA, A. P. et al. Hematological values, plasma protein and fibrinogen of criollo horse-their variation with sex, age and management. Acta Scientiae Veterinariae, 2006. v.34, n.3, p.275-279. Available from: <www.ufrgs.br/favet/revista $>$. Accessed: Apr. 24, 2020.

MORTON, A. J. Diagnosis and treatment of septic arthritis. Veterinary Clinics of North America: Equine Practice, dez. 2005. v.21, n.3, p.627-649. Available from: <https:// linkinghub.elsevier.com/retrieve/pii/S0749073905000507>. Accessed: Apr. 24, 2020.

MOTTA, R. G. et al. Multidrug resistant bacteria isolated from septic arthritis in horses. Pesquisa Veterinaria Brasileira, 2017. v.37, n.4, p.325-330. Available from: <https://www.scielo.br/ scielo.php?script $=$ Sci_arttext\&pid $=$ S0100-736X2017000400325>. Accessed: Apr. 24, 2020.

OLIVE, J. et al. Comparison between palpation and ultrasonography for evaluation of experimentally induced effusion in the distal interphalangeal joint of horses. American Journal of Veterinary Research, jan. 2014. v.75, n.1, p.34-40. Available from: <https://www.ncbi.nlm.nih.gov/ pubmed/24370243>. Accessed: Apr. 23, 2020.

QUINN, P. J. et al. Veterinary Microbiology and Microbial Disease. [S.1.]: Wiley-Blackwell, 2011.

RIBEIRO, M. G. et al. Trueperella pyogenes multispecies infections in domestic animals: a retrospective study of 144 cases (2002 to 2012). Veterinary Quarterly, 3 abr. 2015. v.35, n.2, p.82-87. Available from: $<$ https://www.tandfonline.com/doi/full/1 0.1080/01652176.2015.1022667>. Accessed: Apr. 24, 2020. 
RIBEIRO, M. G. et al. Molecular epidemiology of virulent Rhodococcus equi from foals in Brazil: virulence plasmids of $85-\mathrm{kb}$ type I, 87-kb type I, and a new variant, 87-kb type III. Comparative Immunology, Microbiology and Infectious Diseases, jan. 2005. v.28, n.1, p.53-61. Available from: <http://www.ncbi.nlm.nih.gov/ pubmed/15563953>. Accessed: Apr. 24, 2020.

ROSS, M. W.; DYSON, S. J. Diagnosis and management of lameness in the horse. [S.1.]: [s.n.], 2003.

SCHADE, J. et al. Regional limb perfusion with antimicrobials in horses. Revista de Ciencias Agroveterinarias, 19 jun. 2019. v.18, n.2, p.281-291. Available from: <http://www. revistas.udesc.br/index.php/agroveterinaria/article/view/9341>. Accessed: Apr. 24, 2020.

SCHNEIDER, R. K. et al. A retrospective study of 192 horses affected with septic arthritis/tenosynovitis. Equine Veterinary Journal, nov. 1992. v.24, n.6, p.436-442. Available from: $<$ http://www.ncbi.nlm.nih.gov/pubmed/1459056>. Accessed: Apr. 24, 2020.

SCHWARZ, S. et al. Assessing the antimicrobial susceptibility of bacteria obtained from animals. Veterinary Microbiology, 24 fev. 2010. v.141, n.1-2, p.1-4. Available from: <http://www.ncbi.nlm. nih.gov/pubmed/20042302>. Accessed: Apr. 24, 2020.

STEEL, C. M.;et al., Risk of septic arthritis after intra-articular medication: A study of 16,624 injections in Thoroughbred racehorses. Australian Veterinary Journal, jul. 2013. v. 91, n.7, p.268-273. Available from: <https://pubmed.ncbi.nlm.nih. gov/23782019/>. Accessed: Apr. 24, 2020.

TAYLOR, A. H. et al. Bacterial culture of septic synovial structures of horses: Does a positive bacterial culture influence prognosis? Equine Veterinary Journal, abr. 2010. v.42, n.3, p.213-218. Available from: <https://www.ncbi.nlm.nih.gov/ pubmed/20486977>. Accessed: Apr. 23, 2020.

TUNEV, S. S. et al. Necrotizing mycotic vasculitis with cerebral infarction caused by Aspergillus niger in a horse with acute typhlocolitis. Veterinary Pathology, 1999. v.36, n.4, p.347-351. Available from: <https:/www.researchgate.net/ publication/12878653_Necrotizing_Mycotic_Vasculitis_with Cerebral_Infarction_Caused_by_Aspergillus_niger_in_a_Horse with_Acute_Typhlocolitis $>$. Accessed: Apr. $2 \overline{3}, 2020$.

VÁZQUEZ-BOLAND, J. A. et al. Rhodococcus equi: The many facets of a pathogenic actinomycete. Veterinary Microbiology, 29 nov. 2013. v.167, n.1-2, p.9-33. Available from: <https:// linkinghub.elsevier.com/retrieve/pii/S0378113513003301>. Accessed: Apr. 24, 2020.

VOS, N. J.; DUCHARME, N. G. Analysis of factors influencing prognosis in foals with septic arthritis. Irish Veterinary Journal, 1 dez. 2008. v.61, n.2, p.102. Available from: $<$ https://irishvetjournal. biomedcentral.com/articles/10.1186/2046-0481-61-2-102>. Accessed: Apr. 24, 2020. 